\title{
Organizational Sensegiving: Indicators and Nonprofit Signaling
}

\author{
Jamie Levine Daniel, Adam Eckerd
}

\begin{abstract}
:
Resource acquisition depends upon the agreement between an organization's sense of identity and the perceptions of organizational identity held by resource providers. In order to smooth the flow of resources and buffer against potential issues, organizations seek to manage external perceptions and, to the extent possible, control their organizational identity. Using exploratory factor analysis, we examine data from 300 GuideStar profiles to develop a sense of how nonprofit organizations "give sense" to resource providers and attempt to manage their organizational identity. We find evidence of three sensegiving strategies. We then use a seemingly unrelated regression model to examine the relationship between these strategies and revenue outcomes, finding evidence that a) nonprofit organizations demonstrate intentional sensegiving, and b) different sensegiving approaches are related to different income streams.
\end{abstract}

Keywords: organizational identity, sensegiving, nonprofits, legitimacy, differentiation

This is the author's manuscript of the article published in final edited form as:

Levine Daniel, J., \& Eckerd, A. (2019). Organizational sensegiving: Indicators and nonprofit signaling. Nonprofit Management and Leadership, 30(2), 213-231. https://doi.org/10.1002/nml.21383 


\section{Introduction}

Nonprofit organizations have to satisfy many different stakeholders in order to acquire the resources they need to deliver on their missions. Nonprofit organizations also have perceptions of their identity that manifest in how they deliver their services, as well as the roles they play in their communities (Levine Daniel and Moulton 2017; Moulton and Eckerd 2012). Successful resource acquisition depends, at least in part, upon some level of congruence between an organization's sense of identity and the perceptions of organizational identity held by resource providers (Voss, Cable, and Voss 2006). How do nonprofit organizations manage their identity in order to create this congruence between their own perceptions of organizational identity and those of their stakeholders?

We examine this question using a framework of organizational sensegiving and sensemaking, a two-way feedback system that informs organizational identity (Gioia and Chittipeddi 1991). Organizations provide cues to stakeholders in an effort to convey a particular identity, while at the same time external actors receive those cues and internalize their own distinct and diverse perception of the organization's identity. Identity emerges through the interaction of these cues feeding back to one another: organizations send signals about who they want external actors to perceive them to be and external actors send back perceptions about who they actually think organizations are. Organizations engage in sensegiving as a way of conveying "this is who we say we are." External actors process this through sensemaking ("this is who I perceive you to be"), and engage in sensegiving of their own to attach their perceptions of the organization's identity back to the organization. In turn, the organization makes sense of these external actors' perceptions as it reconsiders how it signals its organizational identity. In this way, an 
organizational identity is never entirely fixed, but rather emerges and adapts over time (Gioia, Schultz, and Corley 2000).

We are specifically interested in the following questions related to this process: (1) is there evidence that organizations demonstrate different sensegiving strategies, and (2) to what extent are these different strategies connected to (successful) resource acquisition? We contribute to the literature on nonprofit organizational identity, and specifically sensegiving, in multiple ways. First, while organizational sensemaking has been widely studied, sensegiving has been less of a focus, particularly in the nonprofit setting. Second, the literature on sensemaking and sensegiving tends to focus on cases where resource providers are also the target market or recipients of the organization's goods or services (e.g.: Chalmers and Balan-Vnuk-Eva 2012; Weick 1995). We focus instead on how organizations manage their sensegiving efforts when the resource providers may or may not be the target market for their services. Third, organizational sensemaking and sensegiving is often linked to organizational crisis or stigma (e.g. Gilstrap, Gilstrap, Holderby, and Valera 2016; Meisenbach, Rick, and Brandhorst 2019) or specific organizational change initiatives (e.g.: Gioia and Chittipeddi 1991). Here we focus on the more day-to-day aspects of organizational identity management as an emergent flow of information between organizations and external actors, paying special attention to sensegiving as an intentional strategy for sustainable resource acquisition. Fourth, many studies rely on qualitative approaches (interviews, artifact collection) that provide depth about specific organizations, but not necessarily statistical generalizability. We utilize a mixed method approach to inductively and qualitatively identify a set of organizational strategies and quantitatively assess the connection between these strategies and different key resource acquisition partners. 
In the following section we provide an overview of organizational identity literature as well as some key theories exploring organizational sensegiving within nonprofits. We then analyze 300 organizational profiles posted online at Guidestar, a charity information repository and watchdog, to see what patterns emerge around language usage and signaling via indicators, evaluation practices, and results. Using these patterns, we then assess the relationship between certain sensegiving strategies and resource acquisition (i.e.: receipt of donations or government funds). Finally, we discuss our findings, identifying trends between sensegiving strategies and receipt of resources from individual donors.

\section{Background}

Organizational identity comprises that which is central, unique, and enduring to an organization (Albert and Whetten 1985). An organization can demonstrate a holographic identity that is consistent across organizational functions and domains, or it can also demonstrate multiple or specialized identities (Albert and Whetten 1985). Organizational identity is a construct that reflects others' perceptions about the organization (Gioia, Schultz, and Corley 2000; Glynn 2000). This identity is a "collectively-held frame" (Golden-Biddle and Rao 1997, 594) between the organization and the actors in its environment. The collective nature of this frame matters for external assessments of legitimacy, acquisition of resources, market share, and stability (Suchman 1995).

Organizations and the actors in their organizational environment engage in sensegiving and sensemaking processes that inform who an organization says it is and how this identity is 
interpreted. That is, while organizations may attempt to exert control over their organizational identity (through marketing, stories and the like), they can only send signals about how they would like to be perceived; they cannot fully control how those signals are received.

Stakeholders and other actors in the environment will receive the signals, bringing in their own preexisting perceptions. This process of sensemaking reflects the interpretation of organizational vision carried out by external actors (Gioia and Chittipeddi 1991). These actors make sense of an organization by considering what the organization itself signals, but also what others in the environment say, as well as their own biases and experiences. Each individual sensemaking process results in a distinct understanding, albeit one that may have much in common with others' understandings as well. While sensemaking is an integral aspect of the process we are describing, it has also been widely studied (Chalmers and Balan-Vnuk-Eva 2012; Elsbach and Kramer 1996; Gephart 1993; Hahn, Preuss, Pinkse, and Figge 2014; Weber, Fann Thomas, and Stephens 2015; Weick 1995). Much less is known about sensegiving, and this is especially true of nonprofit sensegiving.

Sensegiving is the process of disseminating an organizational self-vision or identity to external actors. It differs from marketing or public relations in that the organization is not attempting to sell anything or secure favor, but rather to convey an impression about the organization itself that will change or reinforce its existing identity. That said, organizations can use sensegiving as a deliberate, though indirect, strategy for resource procurement by signaling values to resourcecontrolling audiences (Suchman 1995). 
Sensegiving can take many different forms and organizations can send many different types of signals, depending on the organization's own purposes, values, target audience(s). These signals are present in value statements, word choices for websites and organizational profiles on aggregator websites such as Charity Navigator or Guidestar (with Guidestar being our data source for this paper), images in fundraising appeals, or - for financial resources providers, the types of grants awarded or evaluation metrics emphasized.

Organizations send out signals; external actors have to engage in sensemaking to process these signals. The signals sent must resonate with the audience if the organization is to have any control over its identity with that group of actors. Over time a shared sense of the organizational identity emerges and forms the basis for the understanding of what an organization does and what other actors in its environment expect-ideally (from the organization's perspective) ensuring stakeholder support for the organization and a consistent flow of needed resources. Scherer (2017) captured this process in her study of foundations in which she identified a set of identities that foundations present. Each identity - agenda setter, supporter, community builder was associated with unique behaviors that clearly signaled organizational values. Similarly, when filling out a profile on Guidestar, an organization makes choices about how to convey its identity through the answers it provides (sensegiving). Donors seeking information can review these profiles (sensemaking). The decision to donate or not becomes an act of donor sensegiving. The organization then engages in sensemaking to determine the relative effectiveness of their sensegiving, and the cycle repeats.

As the organization and the other actors "get to know" one another an identity forms. The organization's perception of itself shifts according to external actors' sensemaking and these 
actors' perceptions of the organization shift according to the organization's sensegiving. This identity is not necessarily static (Gioia, Schultz, and Corley 2000), but it is also not entirely unstable. The identity and both the organization's and the external actors' responses to that identity adapt through time as the sensegiving-sensemaking cycle continues. Figure 1 demonstrates the process of organizational sensegiving and sensemaking.

[Figure 1 about here]

\section{Nonprofit Sensegiving}

Certain characteristics and values define nonprofits: they are non-coercive, they do not distribute profits to shareholders, and the lines of accountability are unclear (Frumkin 2002). No one can be compelled or coerced into giving resources to nonprofits. As Frumkin $(2002,4)$ notes, "The flow of resources to a nonprofit depends entirely on the quality of relevance of its mission and its capacity to deliver value." Donors, for example, must trust that organizations are worthy recipients of their financial resources, and this trust is built, in part, on organizational judgement, delivered service quality, and perceived role competence (Sargeant and Lee 2002).

The unclear lines of accountability are due, in part, to the fact that nonprofits do not distribute earnings to owners or shareholders. Instead, these organizations have many stakeholders: clients/beneficiaries, volunteers, employees, public officials, and community residents. Each stakeholder, and each actor in the external environment, has an individual perception of the organization's identity: what the mission is, what the organization should prioritize, how (and to whom) it should deliver services, how competent the organization is, how trustworthy the 
organization is and potentially how it should be evaluated for this service delivery. These perceptions influence how people interpret organizational activities, the organization's response to problems, and the organization's results (Albert and Whetten 1985; Dutton and Dukerich 1991; Dutton, Dukerich, and Harquail 1994). Nonprofits have to balance these priorities in order to procure needed resources and deliver their goods/services (Fassin 2009; Freeman 1994), essentially rendering the organization an agent with multiple principals who may have different goals and priorities (Van Puyvelde, Caers, Du Bois, and Jegers 2012).

Sensegiving activities can include crafting or changing mission statements, engaging in branding campaigns, targeted fundraising, or maintaining an active social media presence. These practices enable organizations to engage in broad sensegiving. However, given the multiple and diverse actors with whom nonprofits must sensegive, nonprofits cannot rely on a narrow set of activities and hope that the same signals will appeal to multiple audiences. If all external actors receive the same message, the communications would need to be so general in nature that making an impression may be difficult. Thus, most nonprofits will need to send different signals to different audiences.

Nonprofits do, of course, tailor different messages to different audiences, for example, via targeted charitable appeals or informational materials. Another mechanism through which nonprofits can signal identity, competence, and trustworthiness to stakeholders, and the mechanism that we study here, is through donor-oriented websites such as Guidestar or Charity Navigator. These sites serve as information repositories and watchdogs that provide financial, 
performance, and governance-related information to potential donors. Unlike a charitable appeal that is targeted at those likely already familiar with an organization and is intended to convince donors to donate, these informational websites serve donors who have generally already decided to donate but have not made a choice about to whom they want to donate. While some of these online profiles are automatically generated without any input from an organization (e.g.: through tax filings, etc.), some, like those on Guidestar, are curated by the nonprofits themselves. Since the audience for these sites usually consists of donors who are seeking out organizations to donate to, organizations can be intentional in the sensegiving actions they take to send signals to a specific set of stakeholders.

While there are many different ways to convey impressions, sensegiving around organizational performance may be a particularly important approach to utilize on sites such as these. The push for more evaluation and evidence-based practice has been well documented in the nonprofit sector over recent decades (Carman and Fredericks 2010; Cordery and Sinclair 2013; Woerrlein and Scheck 2016). Resource-controlling stakeholders want to know how their resources are being used and organizations want to convey their effectiveness as stewards of those donated resources. This may be particularly important for users of watchdog and informational sites who tend to be more sophisticated in their understanding of nonprofit operations and the diversity of choices available. In this way, sites like Guidestar can be viewed as competitive domains wherein nonprofits seek to convey that they are more deserving, more legitimate options for donors than other organizations that may be considered. In order to maintain access to these resources, nonprofit organizations respond to this competitive pressure by providing information intended to convey the organization's effectiveness via whatever informational means they 
choose. For example, if an organization is interested in conveying professionalism, they may opt to provide quantitative indicators such as measures or counts (of the number of people served, or of the amount of grants provided for example), or they may report professional program evaluation results in order to emphasize social change, or outcomes and impact.

This domain is interesting for study for other reasons as well. In a setting where donors are comparing impressions that are given from several organizations, nonprofit organizations need to both conform to some basic expectations of professionalism while also distinguishing themselves from other similar nonprofits. They have to strike a delicate balance between differentiating themselves from their competition as worthy resource recipients (Barman 2002) and maintaining legitimacy as a professional nonprofit, complete with the public trust that entails (e.g.: Hansmann 1980; Sargeant and Lee 2002). Isomorphic pressures may explain why, despite the need for differentiation, certain tropes are constant across organizational profiles on watchdog sites (Eckerd 2014). The push for evidence-based metrics could be reflective of mimetic isomorphism, a "standard response to uncertainty" (DiMaggio and Powell 1983, 150) whereby organizations use evidence-based metrics or professional language because it is what sophisticated donors expect. As DiMaggio and Powell $(1983,149)$ note, mimetic isomorphism occurs "at the level of taken-for-granted assumptions rather than consciously strategic choices." In short, each organization will try to conform to expected operational norms so that external actors will perceive the organization as "doing things the right way" and following procedures that are expected of "legitimate" stewards of resources intended to provide a social good. 
On the other hand, differentiation efforts reflect strategic, proactive, intentional sensegiving. The differentiation occurs not via different operational procedures but rather through signals related to how they deliver services and what effectiveness means. Nonprofits serve many roles in their community (Moulton and Eckerd 2012; Salamon 2003), and these roles influence their approaches to service delivery and their understanding of effectiveness. These organizations can use sensegiving strategies to signal their roles (and, thus, their approaches to service delivery), both illustrating a consistency with expected norms of operations and a differentiation in terms of effectiveness.

However, effectiveness is difficult to define in the sector and organizations can use different ways to signal effectiveness to particular donor audiences. Nonprofits driven by expressive rationales (Frumkin 2002) may frame their missions from a communitarian perspective, evoking their commitment to shared norms and notions such as justice and fairness. In seeking resources, they can choose to signal by describing how embedded their resource acquisition strategies are within their service delivery strategies (Levine Daniel and Kim 2018). Others may operate more instrumentally by illustrating how their activities have directly changed their community, signaling via outcome evaluations or improving trends of clients served.

\section{Data \& Methods}

We explore if and how nonprofits use different sensegiving strategies and the implications of these strategies for revenue generation. To do so, we draw our data from two sources: the Internal Revenue Service (IRS) and Guidestar. General information about the organizations and their finances were gathered from IRS Form 990 tax filings. All other data were either gathered 
from or developed by utilizing information from Guidestar.org. Guidestar describes itself as an information repository that aims to inform a particular, though diverse, nonprofit stakeholder: resource providers. Guidestar identifies its users as resource providers and nonprofit leaders, articulating that "[d]onors [use the site to] explore charities and issues they want to support. Nonprofit leaders benchmark their organizations against their peers. Funders research grantees.". The data on Guidestar are a blend of information from IRS tax filings, information gleaned by Guidestar from organizational information, and information provided by the organization for inclusion on the site. Given that the stated intention of Guidestar is to inform donors, we limit our study to assessing the effect of sensegiving strategies on financial outcomes, but we recognize that sensegiving to donor audiences is but one means of sensegiving to one set of stakeholders. There may be other sensegiving processes as they relate to volunteers or in-kind contributions, but in this case, we assume that nonprofits that opt to provide detailed information to Guidestar are doing so to reach the primary audience Guidestar notes itself as serving: financial donors. We describe our variables and sample below, discussing our independent variables first as part of describing our sampling approach. We then describe our sample, dependent variable, and methods.

\section{Sensegiving Variables and Sample}

To assess whether we can find evidence of nonprofit sensegiving, we first identify a set of variables consistent with potential modes of sensegiving. Our goal here is to begin a conversation about sensegiving in the nonprofit sector. Since there is very little theory or empirical work to provide guidance about nonprofit sensegiving strategies, we follow an

\footnotetext{
${ }^{1}$ Quote from https://learn.guidestar.org/about-us retrieved Aug 24, 2018.
} 
exploratory approach. Further, given that sensegiving signals are, by their very nature, interpretive, our approach to identifying them was to interpret the nature of the messages that the organizations send. We used the public-facing information that organizations self-report to Guidestar to populate their profiles on the site. This intentional and self-reported information includes the organization's mission statement, location, and basic financial information (such as the organization's balance sheet and statement of revenues and expenses).

The web page also includes a section entitled "Programs + Results" that enables the organization to post whatever information it deems relevant to convey the extent to which its programs are successful and/or valuable. In this section, the organization has the opportunity (and indeed can take the initiative) to highlight and describe certain programs and the logic underlying them. It also has the opportunity to provide data or information about the accomplishments of the program. This can include quantitative information (often presented in pie or bar charts) or descriptions and details about the work. Organizations can populate these sections from a large number of pre-set quantitative metrics provided in the Guidestar platform or provide their own commentary and metrics, choosing their preferred means of presenting themselves. Guidestar also encourages organizations to provide the answers to five questions about their products/services:

1. "What is the organization aiming to accomplish?"

2. "What are the organization's key strategies for making this happen?"

3. "What are the organization's capabilities for doing this?"

4. "How will they know if they are making progress?"

5. "What have and haven't they accomplished so far?" 
Organizations provide a few sentences in response to these questions - but crucially for our purposes, organizations may frame their programs, strategies, capabilities, and results in any manner they choose.

In short, the Guidestar listing presents organizations with the opportunity to frame the story of their accomplishments in any manner that appeals to users of the site, making this listing a sensegiving opportunity. For the purposes of our study this is also a clear opportunity to reach a particular, if still diverse, set of environmental actors. Guidestar identifies its users as resource providers and nonprofit leaders.

Using the information in the "Programs + Results" section, we undertook an interpretive content analysis (Krippendorff 2013) to identify the sensegiving strategies organizations use to appeal to resource providers. We assessed these strategies inductively and utilize content analysis methods with individual coders reviewing multiple organizational listings based on an assessment of common language types and common ways that nonprofits tend to provide performance information.

For our sample, we first selected a group of organizations from Guidestar's full list of approximately 55,000 nonprofits that have provided at least some basic information to Guidestar. Guidestar awards organizations a "Seal of Transparency" ranging from (from low to high) Bronze, Silver, Gold, and Platinum levels based on how much information organizations are willing to voluntarily self-report. We ultimately only considered the roughly 18,000 profiles that 
had reached at least the Gold level, as the "Programs + Results" sections were largely empty at the lower levels and we wanted to assess the information that organizations intentionally chose to present. We acknowledge the potential bias of this sample as inclusion in our study would be predicated on an active desire to reach the Guidestar audience, but we argue that, given the aim of our work here to understand sensegiving efforts to specific audiences, this does not limit the generalizability of our findings. From this list, we randomly selected 300 organizations. We selected this number in order to balance our ability to conduct a robust analysis with our coders' ability to review the profiles. We received assistance from 10 different coders. Most coders reviewed 25 distinct organizations each (although some coders did more or fewer), and an additional 3 organizations that were consistent across all coders in order to assess intercoder reliability (discussed below). Coding was conducted in late 2016; thus, our assessment of sensegiving strategies was current as of the 2016 fiscal year for most of the organizations in our sample.

Codes were developed primarily inductively from an initial scan of the first 30 organizations in the sample. The primary coder reviewed these profiles to identify the different types of information, data, and communications strategies that the organizations were employing. The information presented shared commonalities and the language use was similar to the typology of language use observed by Williams and Matheny (1995), who describe two types of language use relevant for our purposes: managerial and communitarian. Managerial language is language that is professional in nature, hewing to statements of service delivery, fact, evidence, data and results, as well as a professional process of management. Communitarian language is more value-oriented in nature, describing the expressive values that the organization serves, 
articulating the value of services provided from a moral perspective. While Williams and Matheny (1995) focused on the use of language in policy argumentation, their general premise fits well with nonprofit sensegiving. They argued that the underlying logics of the different approaches to language needed to be consistent amongst policy stakeholders if a policy response was to be effective; the language approach is the means through which that shared logic is communicated. We see a corollary with sensegiving-if nonprofits seek to reach certain audiences with their messages, then it would make sense to speak in the language to which those audiences would most relate. We therefore assessed whether the organizations conveyed information in managerial-oriented and/or communitarian-oriented language.

We also identified the type of data that nonprofits provided to illustrate their effectiveness. For example, organizations could provide data about inputs, outputs, specific types of information about volunteers or reporting requirements, or anecdotes about successes. Finally, we sought further detail in the type of information that was provided, for example whether organizations reported things like the number of people served, the number of volunteers, or outcome oriented results. All codes are dichotomous - either the organization presented this type of data or it did not. The full list of codes is shown in Table 1, along with a description of the variable and the proportion of organizations coded as presenting that particular type of information.

These codes were explained to the coders with a detailed list of the definition of the code and some key words/metrics/ideas that illustrated the concept—-basically a fuller definition of the code description shown in Table 1. The coders then simply identified if the organization 
provided evidence or description matching the concept of the code. All were coded dichotomously, indicating either the presence or absence of the utilization of a particular piece of information or style of communication. As noted, the reviewers all reviewed the same 3 organizations at some point in their list of organizations to code. Each of the coders' sheets for these three organizations were used to calculate the extent of agreement amongst the coders. We calculated a Krippendorff's alpha of .811 , which is above the generally accepted level of .80 to indicate the validity of the coding schema. The different concepts are described, along with the proportion of the 300 organizations that were coded as utilizing this type of information in Table 1.

[Table 1 about here]

We conducted an exploratory factor analysis of most of the variables identified in Table 1 to see what definable sensegiving patterns would emerge in the data. ${ }^{2}$ We followed this approach with an understanding of the limitations of an exploratory factor analysis. First, we cannot be certain that we have included the correct set of predictive variables for uncovering the latent sensegiving constructs. However, we hope that we have mitigated this possibility by using an inductive approach informed by theory (as described above) that is, by design, emergent and flexible (Van Maanen 1998). Second, as with any exploratory factor analysis, our results may well just be artifacts of this particular set of organizations, but as the sensegiving conversation continues our set of variables and identified factors can hopefully be replicated and refined to better reveal the latent strategies we uncovered. Finally, we ran the exploratory factor analysis in several different

\footnotetext{
${ }^{2}$ We excluded the inputs variable from the final factor analysis over potential collinearity concerns with other variables in the set.
} 
ways to assess the robustness of the factors that emerged, finding that regardless of the variables we included or excluded, the factors that we describe below consistently emerged from the data.

The results are included in Table 2. As shown, three factors were identified. As we noted above, there are a number of trends with respect to how nonprofits both manage their performance and relate that performance to the public, and these trends are quite consistent with the factors that were identified in our analysis: the ongoing trend of professionalization of the sector (Eikenberry and Kluver 2004); the push towards more evidence-based, outcome-oriented evaluation practices (Woerrlein and Scheck 2016); and the use of symbolic evaluative information as a means of satisfying stakeholder preferences (Eckerd and Moulton 2011; Benjamin 2012).

The first factor, professionalism, loads high on the managerial code and low on communitarian, indicating that organizations had a tendency to be professionally oriented or moralistic in their language, but not both. It is perhaps not surprising that nonprofits tend to use one approach or the other, but not both. The second factor, outcomes, loads high each of our outcome codes. This factor seems to reflect that organizations that measured outcomes tended to measure outcomes from different approaches, whereas those that did not report outcomes did not tend to report any outcomes at all. Finally, we are calling the third factor the symbolic factor, as it relates to output measures that tend to relate to organizational activities and can show year to year changes or improvements (Eckerd and Moulton 2011). Again, if organizations tended to report one type of symbolically-oriented metric, then they also tended to report others as well.

[Table 2 about here] 
In the regression models described below, we include these three factor scores for each organization as our independent variables and indicators of the extent to which organizations followed three different sensegiving strategies: professionalism, outcome/evidence-based orientation, or symbolic appeal to improvement. In general, the organizations in our sample tended to utilize the professionalism and symbolic sensegiving approaches a bit more than the outcome-oriented approach, with factor score means of $.40, .37$, and .26 , respectively. Further, as would be expected from a factor analysis approach, there are no significant correlations between these factor scores, although organizations that utilized professionalism were more likely to pair that approach with symbolic information than with outcome information, and those that that used an outcome approach were more likely to pair that with a symbolic approach than with professionalism.

\section{Dependent and Control Variables}

Dependent and control variables were obtained from organizational and financial data maintained by Guidestar. These data are primarily derived from the nonprofits' IRS Form 990 tax returns. The most recent available tax year data were used for each organization, which in this case was from 2016 or 2017 returns. We preferred 2017 financial data, where available, but used 2016 if necessary. This ensures that in all cases our observation of sensegiving occurred prior to, or at least concurrently, with the financial information. We assess three dependent variables in two different ways, all related to the relative mix of revenue for the organizations. These variables are intended to indicate the primary sources from which the nonprofits acquire resources and thus suggest the intended audience for their sensegiving activities on Guidestar. In 
one set of models we consider the proportion of total revenue the organization received during the year from donations, government grants, and earned income, reasoning that these proportions represent different audiences that the organizations may be trying to reach with their sensegiving strategies. In a second set of models, we look at year-over-year percent changes in these same variables to assess the extent to which the sensegiving strategy is associated with improvements in revenue over time. In general, these changes reflected the percent change in donations, government grants, and earned income from 2016 to 2017.

We also include control variables from these data to account for the organization's age (in years from 2017, under the expectation that older organizations may be more professionalized), size (in both logged total assets and total income, under a similar expectation of professionalization), and an indicator of the extent of public fundraising efforts, a simple dichotomous indicator as to whether the organization did not report any fundraising expenses (which is the case for $27 \%$ of our sample), to differentiate between organizations that are more or less reliant on fundraising versus other revenue generating strategies. Summary statistics for these variables are provided in Table 3.

[Table 3 about here]

While our three dependent variables represent different revenue streams, they are interdependent with one another, as a high proportion of revenue from one stream necessarily is related to a low proportion in another. In order to account for these endogeneity issues, we use a seemingly unrelated regression (SUR) model. A SUR model simultaneously estimates multiple regression equations accounting for the dependence in the dependent variables and the covariates. 
Essentially, a SUR model is a system of standard regression models that incorporates a weighting matrix into the calculations of the error terms associated with each covariate. This assures that the mutual dependence in the models is accounted for outside of the relationship between the independent and dependent variables for each distinct equation. Given the likely presence of heteroskedastic errors, all models were estimated with bootstrapped robust standard errors. Finally, we included each organization's National Taxonomy of Exempt Entities (NTEE) Major code to account for likely variation in funding sources from organizations that carry out distinct missions, and estimated the models with bootstrapped robust standard errors by NTEE designation. $^{3}$

\section{Findings}

Table 4 shows our SUR model assessing the connection between sensegiving approaches and revenue sources. Table 5 shows our results assessing the connection between sensegiving approaches and the change in revenue from these sources. Although a SUR is actually a system of models, we present the data in Tables 4 and 5 as results are usually presented for standard regression models and simply note that the mutual dependence between these regressions was accounted for in our modeling technique. We also exclude our NTEE indicator variables, for which there were no discernable trends, from the table below for readability.

[Table 4 about here]

[Table 5 about here]

\footnotetext{
${ }^{3} \mathrm{We}$ considered a variety of different modeling strategies, including independent models for each dependent variable, clustered standard errors by NTEE code, and by excluding our factor scores and just using the coded responses as independent variables. Our key findings and interpretations were robust to each of these different approaches. We opted to present the results of the SUR models as we believe this to be the most appropriate modeling approach.
} 
The first thing to note in Tables 4 and 5 is that the symbolic approach is not associated with any of our revenue outcome categories. This does not necessarily suggest that none of the donor audiences are concerned about more symbolic approaches, but it may indicate that symbolic approaches are so ingrained at this point that it is difficult for an organization to move the needle when focusing on more output-oriented approaches. That is, if everyone is reporting outputs, as $81 \%$ of our sample is doing, symbolic sensegiving may be a means through which to illustrate legitimacy rather than a means through which to illustrate differentiation.

Our results suggest that the outcome and professionalism approaches may be used more for purposes of differentiation. An increased reliance on an outcome strategy is associated with a higher proportion of revenue from donations and from government grants, and a lower proportion from earned income. This may indicate that nonprofits are interested in providing potential donors with a sense that they take an evidence-based approach in assessing their effectiveness. For many donors, and in particular, for more sophisticated donors like government grantors or individual donors that would investigate nonprofits on Guidestar, this may signal an organization that is not interested in simply having good intentions but also following up with an assessment of program outcomes to inform their determinations of program effectiveness. Interestingly, however, an increased reliance on this outcome orientation is associated with a decrease in revenue from government grants from one year to the next. We find this result unintuitive, but do note that the ramifications of the change in federal government power from 2016 to 2017 may simply have been a reflection of an overall decrease in governmental funding that was available from the federal level. 
An increased utilization of a professionalism approach is more straightforwardly associated with an increase in the proportion of revenue from donations and government grants, and an increased amount of government funding from one year to the next. We interpret this result similar to the outcome strategy. Given the sophisticated donor base that uses Guidestar and that provides government grants, organizations that seek to connect with the audience of Guidestar will want to convey that they are professionally managed organizations that utilize donated resources appropriately.

Finally, we find very little indication that these sensegiving strategies have effects on earned revenue. We do not find this particularly surprising for a couple of reasons. First, earned income from direct service provision represents (a) self-sustaining income stream(s) for the organization. Organizations may not feel the need to target messages on Guidestar to this particular audience, given that Guidestar is focused on donors rather than those who purchase or are otherwise recipients of organizational goods or services. Earned income is also transactional in nature clients receive some good or service in return. In this light, the nonexistent and negative relationships between earned income and sensegiving approaches appears logical. Clients paying fees receive tangible goods or services, so nonprofits do not need to use broader outcomes-based or symbolic narrative strategies to solicit this type of revenue. It may be the case that organizations follow sensegiving strategies for clients and services recipients via other means, like marketing strategies, but they do not seem to target this particular revenue stream via Guidestar. 
Finally, our control variables are generally not associated with particular sensegiving strategies, with one important exception. First, age is associated with different revenue sources (negatively with donations and positively with government grants and earned revenue), but with coefficients that suggest little practical significance. One key meaningful relationship is between the reporting of zero fundraising expenses and the change in donated resources. Given little actual variation in fundraising expense ratios, we opted to measure fundraising approaches via a dichotomous indicator regarding whether the organization reported any fundraising expenses or none. We find that the reporting of zero fundraising expenses in one year (again, true of $27 \%$ of our sample) is associated with over a $6 \%$ increase in donations in the following year. We describe our interpretation of this finding in the discussion section below.

\section{Discussion}

Nonprofits need to forge an identity if they hope to maintain stability and access to resources. Actors in the external environment will make sense of an organization based upon their own individual perceptions and experiences with the organization, but organizations may have some ability to influence this sensemaking through their own sensegiving strategies. While sensemaking has been studied, there is comparatively little research about sensegiving, particularly for nonprofit organizations. Our aim in this article is to begin a conversation on nonprofit sensegiving and the various ways that nonprofits seek to influence how actors in the external environment arrive at their own perceptions of the organization's identity.

We thus had two key goals in this research: (1) to identify different nonprofit sensegiving strategies, and (2) to assess the extent to which these strategies seemed to be influential in 
reaching the intended audiences for them. Using information that organizations voluntarily provide to Guidestar, we were able to identify three distinct sensegiving strategies that nonprofits employ: an appeal to professionalism and going about their business in the ways that sophisticated donors might expect; an appeal to the extent to which the organization is driven by outcomes or results along with an illustration of what those results are; and an appeal to the process through which they attempt to achieve their mission focusing on reporting information that is likely to have symbolic value to actors in the external environment.

In general, we found that an outcome-oriented sensegiving strategy is associated with receipt of a higher proportion of revenue from donations and government and a lower proportion of earned revenue. We found that a professionalism strategy was associated with more revenue from government and donations, and with an increased amount of government grants. Logically, this makes sense as described above — organizations following these strategies on Guidestar are likely trying to appeal to relatively sophisticated potential donors. We therefore note that this finding places boundaries around our research here—-both the sensegiving strategies that our factor analysis revealed and the results of those strategies for revenue suggest that nonprofits view Guidestar users as sophisticated donors who seek organizations that are professional in their operations and evidence-based in their decision making.

That said, it is still somewhat surprising that the symbolic strategy is not associated with any revenue variables. As noted above, this may indicate that symbolic approaches are more about conformity than differentiation, but it may also be that organizations might be overthinking what is symbolically important. In light of our finding that reporting no fundraising expenses is associated with fairly dramatic increases in donations, a donor for whom symbolic results are 
important may not look much beyond basic expense ratios. The pressure organizations feel to report low overhead (and low fundraising in particular) is well documented at this point (Eckerd 2014) and our results suggest that there may be a tangible benefit to doing so. Despite the contradictory nature of the result, reporting no fundraising expense results in more donations. While reconciling the incoherence of this result is beyond our scope here, we can infer that organizations feel a pressure to symbolically report no fundraising expenses.

We do not, however, assume that these are the only strategies employed and only audiences for whom these strategies are employed. The audience that uses Guidestar is likely a relatively sophisticated set of donors. At the very least, it is a set of donors that has attempted to seek further information beyond that which the organization may provide to them directly. Nonprofits may utilize a plethora of different sensegiving strategies to appeal to different audiences via different means. Thus, our results here probably are best considered an attempt to ascertain how nonprofits appeal to more educated donors rather than other donor types or stakeholders.

We nevertheless still see this as a proof of concept that nonprofits do indeed utilize different sensegiving strategies and that those strategies have implications for organizational performance. It is our hope that this article spurs others to consider other circumstances of sensegiving and begins to build a literature that acknowledges that nonprofits are not mere bystanders who are reactive to how stakeholders make sense of them, but rather actors intentionally engaged in trying to spur stakeholders to develop particular senses of who an organization is. Future research may include considering more specific outlets for information, such as organizational 
websites, to determine a) sensegiving strategies and b) alignment with strategies used in a general outlet like Guidestar. The influence of nonprofit roles, sector, and board/client overlap all provide interesting areas to explore, as well. For example, nonprofits may consistently use certain sensegiving strategies across all outlets (website, Guidestar, etc.) if their key stakeholders overlap, such as art museums where the patrons are also the board members. However, the board members who oversee human services organizations (e.g.: a food pantry) are most likely not the agency's core clientele, so these organizations may vary their sensegiving approaches depending on the outlet. In addition, outlets like Guidestar, or even an organization's own website, often start with the premise that someone has decided to donate (or is considering making a donation) and needs information on where to donate. If the fundraising mechanism is peer-to-peer (e.g.: Chapman, Masser, and Louis, 2019), (how) does organizational sensegiving occur, and to what effect? Lastly, we also encourage the exploration of sensegiving strategies in service of securing resources beyond donations, such as time and in-kind donations.

We also want to note some limitations of our study. First, we effectively utilize a cross sectional design here, only considering a one-year change in revenue. While we intend to follow this sample over time in order to develop the ability to make such observations, this first foray into nonprofit sensegiving is limited to the 2015-2017 timeframe and broader trends may be identifiable with a longer time series of data. We also reiterate here that sensegiving is distinct from fundraising or marketing and is intended to reach broader audiences of organizational actors. Owing to the data available on Guidestar, we were limited in assessing the stakeholder response to particular broad categories of revenue providers and one-year changes. Although we believe that looking at revenue providers is the best approach given the people who use 
Guidestar, this presents a somewhat limited view of what sensegiving is intended to accomplish. Finally, although we took several steps to limit potential bias in this study, there are a few sources of potential bias. First, the generalizability of our sample is limited to organizations that opted to seek Guidestar's gold or platinum designation. These are likely already larger and more professional organizations than the bulk of nonprofits, and this may have implications for the sensegiving strategies that we identified. Secondly, as with any content analysis approach we took steps to minimize bias and validate the approach, but we acknowledge bias may remain. Finally, while we maintain that an exploratory factor analysis was an appropriate method for identification of sensegiving strategies in the absence of clear theoretical guidance, we acknowledge that the strategies we identified may be statistical anomalies. While the strategies we identified make logical sense and fit with the nonprofit literature, they currently lack complete validation. We count on future studies to refine and improve the approach we have taken here.

\section{Conclusion}

In this research, we set out to examine how nonprofits engage in sensegiving to influence how actors in the external environment help the organization form its identity. We explored this question by looking at the profiles that nonprofits intentionally provide to Guidestar and revenue data from IRS 990 tax filings to connect sensegiving approaches to reach various different revenue-providing audiences. First, we used factor analysis to identify three types of sensegiving approaches: professionalism, an output and results orientation, and a process focus on symbolically important information. Second, we find a significant positive relationship between an outcome orientation approach and a professionalism approach with both donations and government revenue. Taken together, we take this to mean that it is likely that a) nonprofit 
organizations demonstrate intentional sensegiving, and b) different sensegiving approaches are related to different income streams and audiences. This illustrates our main goal in this article. We aim to push forward a literature that examines deliberate sensegiving strategies by nonprofits to reach particular sensemaking audiences.

\section{References}

Albert, S., \& Whetten, D. A. (1985). Organizational Identity. Research in Organizational Behavior, 7, 263-295. https://doi.org/10.1017/CBO9781107415324.004

Barman, E. A. (2002). Asserting Difference: The Strategic Response of Nonprofit Organizations to Competition. Social Forces, 80(June), 1191-1222.

Benjamin, L. M. (2012). Nonprofit organizations and outcome measurement: From tracking program activities to focusing on frontline work. American Journal of Evaluation, 33(3), 431-447.

Carman, J. G., \& Fredericks, K. A. (2010). Articles Evaluation Capacity and Nonprofit Organizations Is the Glass Half-Empty or Half-Full? American Journal of Evaluation, 31(1), 84-104. https://doi.org/10.1177/1098214009352361

Chalmers, D. M., \& Balan-Vnuk-Eva. (2012). Innovating not-for-profit social ventures: Exploring the microfoundations of internal and external absorptive capacity routines. International Small Business Journal, 31(7), 785-810. 
Chapman, C. M., Masser, B. M., \& Louis, W. R. (2019). The Champion Effect in Peer-to-Peer Giving: Successful Campaigns Highlight Fundraisers More Than Causes, Nonprofit and Voluntary Sector Quarterly 48(3), 572-592. https://doi.org/10.1177/0899764018805196

Cordery, C., \& Sinclair, R. (2013). Measuring performance in the third sector. Qualitative Research in Accounting \& Management, 10(4), 196-212.

DiMaggio, P. J., \& Powell, W. W. (1983). The Iron Cage: Institutional Isomorphism and Collective Rationality in Organizational Fields. Amercican Sociological Review, 48(2), 147-160. https://doi.org/10.2307/2095101

Dutton, J. E., \& Dukerich, J. M. (1991). Keeping an Eye on the Mirror: Image and Identity in Organizational Adaptation. The Academy of Management Journal, 34(3), 517-554.

Dutton, J. E., Dukerich, J. M., \& Harquail, C. V. (1994). Organizational Images and Member Identification. Administrative Science Quarterly, 39(2), 239-263.

Eckerd, A. (2014). Risk management and risk avoidance in agency decision making. Public Administration Review, 74(5), 616-629.

Eckerd, A., \& Moulton, S. (2011). Heterogeneous roles and heterogeneous practices: Understanding the adoption and uses of nonprofit performance evaluations. American Journal of Evaluation, 32(1), 98-117.

Eikenberry, A. M., \& Kluver, J. D. (2004). The marketization of the nonprofit sector: civil society at risk? Public Administration Review, 64(2), 132-140.

Elsbach, K. D., \& Kramer, R. M. (1996). Members’ Responses to Organizational Identity Threats: Encountering and Countering the Business Week Rankings. Administrative Science 
Quarterly, 41(3), 442-476.

Fassin, Y. (2009). The Stakeholder Model Refined. Journal of Business Ethics, 84, 113-135.

Freeman, R. E. (1994). The Politics of Stakeholder Theory: Some Future Directions. Business Ethics Quarterly, 4(4), 409-421.

Frumkin, P. (2002). On being nonprofit : a conceptual and policy primer. Cambridge, MA: Harvard University Press.

Gephart Jr., R. P. (1993). The Textual Approach : Risk and Blame in Disaster Sensemaking. The Academy of Management Journal, 36(6), 1465-1514.

Gilstrap, C. A., Gilstrap, C. M., Holderby, K. N., \& Valera, K. M. (2016). Sensegiving, Leadership, and Nonprofit Crises: How Nonprofit Leaders Make and Give Sense to Organizational Crisis. Voluntas, 27(6), 2787-2806.

Gioia, D. A., \& Chittipeddi, K. (1991). Sensemaking and Sensegiving in Strategic Change Initiation. Strategic Management Journal Strategic Management Journal, 12(12), 433-448.

Gioia, D. A., Schultz, M., \& Corley, K. G. (2000). Organizational Identity, Image, and Adaptive Instability. The Academy of Management Review, 25(1), 63-81.

Glynn, M. A. (2000). When Cymbals Become Symbols: Conflict Over Organizational Identity Within a Symphony Orchestra. Organization Science, 11(3), 285-298. https://doi.org/10.1287/orsc.11.3.285.12496

Golden-Biddle, K., \& Rao, H. (1997). Breaches in the Boardroom: Organizational Identity and Conflicts of Commitment in a Nonprofit Organization. Organization Science, 8(6), 593611. 
Hahn, T., Preuss, L., Pinkse, J., \& Figge, F. (2014). Cognitive frames in corporate sustainability: Managerial sensemaking with paradoxical and business case frames. Academy of Management Review, 39(4), 463-487.

Hansmann, H. B. (1980). The role of nonprofit enterprise. The Yale Law Journal, 89(5), 835901.

Krippendorff, K. (2013). Content analysis: an introduction ( $3^{\text {rd }}$ ed.). Los Angeles, CA: Sage.

Levine Daniel, J., \& Kim, M. (2018). The Scale of Mission-Embeddedness as a Nonprofit Revenue Classification Tool: Different Earned Revenue Types, Different Performance Effects. Administration \& Society, 50(7), 947-972. https://doi.org/10.1177/0095399716647152

Levine Daniel, J., \& Moulton, S. (2017). Beyond Cans and Capacity: Nonprofit Roles and Service Network Objectives in an Emergency Food Network. Nonprofit Management \& Leadership, 28(1), 47-64.

Meisenbach, R. J., Rick, J. M., \& Brandhorst, J. K. (2019). Managing occupational identity threats and job turnover: How former and current fundraisers manage moments of stigmatized identities. Nonprofit Management \& Leadership, 29(3), 383-399. https://doi.org/10.1002/nml.21332

Moulton, S., \& Eckerd, A. (2012). Preserving the Publicness of the Nonprofit Sector. Nonprofit and Voluntary Sector Quarterly, 41(4), 656-685. https://doi.org/10.1177/0899764011419517

Salamon, L. M. (2003). The resilient sector: The state of nonprofit America. Washington, DC: 
Brookings Institution Press.

Sargeant, A., \& Lee, S. (2002). Individual and Contextual Antecedents of Donor Trust in the Voluntary Sector. Journal of Marketing Management, 18(7-8), 779-802. https://doi.org/10.1362/0267257022780679

Scherer, S. C. (2017). Organizational identity and philanthropic institutions. Nonprofit Management \& Leadership, 28(1), 105-123. https://doi.org/10.1002/nml

Suchman, M. C. (1995). Managing Legitimacy: Strategic and Institutional Approaches. The Academy of Management Review, 20(3), 571-610. https://doi.org/10.2307/258788

Van Maanen, J. 1998. Different Strokes: Qualitative Research in the Administrative Science Quarterly from 1956 to 1996. In Qualitative Studies of Organizations, edited by J. Van Maanen,ix-xxxii. Thousand Oaks, CA: SAGE Publications.

Van Puyvelde, S., Caers, R., Du Bois, C., \& Jegers, M. (2012). The Governance of Nonprofit Organizations. Nonprofit and Voluntary Sector Quarterly, 41(3), 431-451. https://doi.org/10.1177/0899764011409757

Voss, Z.G., Cable, D.M., \& Voss, G.B. (2006). Organization Identity and Firm Performance: What Happens When Leaders Disagree about 'Who We Are?' Organization Science, 17(6), $677-775$.

Weber, M. S., Fann Thomas, G., \& Stephens, K. J. (2015). Organizational Disruptions and Triggers for Divergent Sensemaking. International Journal of Business Communication, 52(1), 68-96. https://doi.org/10.1177/2329488414560281

Weick, K. E. (1995). Sensemaking in Organizations. Thousand Oaks, CA: SAGE Publications. 
Williams, B. A., \& Matheny, A. R. (1995). Democracy, dialogue, and environmental disputes: The contested languages of social regulation. Yale University Press.

Woerrlein, L. M., \& Scheck, B. (2016). Performance management in the third sector: A literature-based analysis of terms and definitions. Public Administration Quarterly, 40(2), $220-255$.

Yong, A.G., and Pearce, S. (2013). A beginner's guide to factor analysis: Focusing on exploratory factor analysis. Tutorials in Quantitative Methods for Psychology. 9(2): 79-94. 
Table 1: Coding Definitions and Descriptive Statistics

\begin{tabular}{|c|c|c|}
\hline & Coding Instructions & Proportion Coded 1 \\
\hline Managerial & $\begin{array}{l}\text { Enter } 1 \text { if the organization uses language that seems to be } \\
\text { very professional in nature }\end{array}$ & .56 \\
\hline Communitarian & $\begin{array}{l}\text { Enter } 1 \text { if the organization uses language that is much } \\
\text { more moralistic in nature }\end{array}$ & .43 \\
\hline Anecdotes & $\begin{array}{l}\text { Enter } 1 \text { if there is any indication that the organization } \\
\text { currently tracks success stories or detailed qualitative } \\
\text { information about selected organization stakeholders }\end{array}$ & .14 \\
\hline Inputs (counts) & $\begin{array}{l}\text { Enter } 1 \text { if they track any input data. Inputs would be } \\
\text { resources that the organization uses in its programs such as } \\
\text { donations received, donors, volunteers, staff, grants } \\
\text { received }\end{array}$ & .51 \\
\hline Outputs (counts) & $\begin{array}{l}\text { Enter } 1 \text { if they track any output data. Outputs are the direct } \\
\text { things that organizations produce. }\end{array}$ & .81 \\
\hline Volunteer counts & $\begin{array}{l}\text { Enter } 1 \text { if the organization tracks the number of volunteers } \\
\text { it has }\end{array}$ & .19 \\
\hline Partnership counts & $\begin{array}{l}\text { Enter } 1 \text { if the organization tracks the number of other } \\
\text { organizations that it partners with, or if it counts the } \\
\text { number of other organizations to whom it has provided } \\
\text { grants }\end{array}$ & .18 \\
\hline Donations noted & $\begin{array}{l}\text { Enter } 1 \text { if the organization tracks some metric related to } \\
\text { the amount of money it receives }\end{array}$ & .15 \\
\hline Media/Internet counts & $\begin{array}{l}\text { Enter } 1 \text { if the organization tracks the number of media } \\
\text { mentions, some measure of social media activity, the } \\
\text { number or return from the events that it holds, or the } \\
\text { number of times the web site is visited }\end{array}$ & .16 \\
\hline Financial stability & $\begin{array}{l}\text { Enter } 1 \text { if the organization indicates that some measure of } \\
\text { financial sustainability is an indicator for success }\end{array}$ & .13 \\
\hline Reporting & $\begin{array}{l}\text { Enter } 1 \text { if the organization specifically mentions that it } \\
\text { reports information to either outside regulators, funders, or } \\
\text { to the board directors }\end{array}$ & .10 \\
\hline Low overhead noted & $\begin{array}{l}\text { Enter } 1 \text { if the organization says anything about their low } \\
\text { fundraising or administrative costs }\end{array}$ & .04 \\
\hline Professional auditor & $\begin{array}{l}\text { Enter } 1 \text { if the organization indicates that it uses the } \\
\text { services of a professional auditor }\end{array}$ & .06 \\
\hline Aggregate output change & $\begin{array}{l}\text { Enter } 1 \text { if the organization tracks some mean or aggregated } \\
\text { output measure. That is, something like the average } \\
\text { characteristics of the recipient group or the average } \\
\text { number of clients served in a given time period }\end{array}$ & .25 \\
\hline Survey/Satisfaction rating & $\begin{array}{l}\text { Enter } 1 \text { if the organization indicates that it does any sort of } \\
\text { survey to assess how satisfied either clients or donors are } \\
\text { with its services }\end{array}$ & .15 \\
\hline Outcomes & $\begin{array}{l}\text { Enter } 1 \text { if the they track outcomes. Outcomes are the } \\
\text { broader things organizations will try to achieve. For } \\
\text { example, the food pantry might track the reduction of } \\
\text { malnutrition in the community, or the animal welfare } \\
\text { group might track the reduction of pet homelessness. } \\
\text { Outcomes should be about the broader change in the } \\
\text { community that directly relates to the mission }\end{array}$ & .41 \\
\hline Counts of outcomes & $\begin{array}{l}\text { Enter } 1 \text { if the organization tracks outcomes and those } \\
\text { outcomes are a count of the number of something }\end{array}$ & .21 \\
\hline Change rates of outcomes & $\begin{array}{l}\text { Enter } 1 \text { if the organization tracks some change in } \\
\text { community or client characteristics over time }\end{array}$ & .15 \\
\hline
\end{tabular}

Note: $\mathrm{N}=300$ 
Table 2: Factor Analysis of Nonprofit Self-Reporting on Guidestar

\begin{tabular}{|c|c|c|c|}
\hline & Professionalism Factor & Outcomes Factor & Symbolic Factor \\
\hline Managerial & 0.861 & & \\
\hline Communitarian & -0.862 & & \\
\hline Anecdotes & & & \\
\hline Outputs (counts) & & & 0.459 \\
\hline Volunteer counts & & & 0.382 \\
\hline Partnership counts & & & \\
\hline Donations noted & & & 0.329 \\
\hline Media/Internet counts & & & \\
\hline Financial stability & & & \\
\hline Reporting & & & \\
\hline Low overhead noted & & & \\
\hline Professional auditor & & & \\
\hline Aggregate output change & & 0.570 & \\
\hline Survey/Satisfaction rating & & & \\
\hline Outcomes & & 0.625 & \\
\hline Counts of outcomes & & 0.564 & \\
\hline Change rates of outcomes & & 0.567 & \\
\hline
\end{tabular}

Notes: Principle components factor analysis with varimax rotation. $\chi^{2}=868.7, \mathrm{p}<.01, \mathrm{n}=301$. Three factors with eigenvalues greater than 1 were retained and extracted; factor loadings on the 3 retained factors are shown above, for all loadings stronger than .32 in either direction (Yong and Pearce 2013).

Table 3: Summary Statistics

\begin{tabular}{lcc}
\hline Variable & Mean & Standard deviation \\
\hline Proportion of revenue from contributions & 0.777 & 0.287 \\
Proportion of revenue from government grants & 0.076 & 0.187 \\
Proportion of revenue from earned income & 0.171 & 0.250 \\
Percent change in contributions (2016-2017) & 0.995 & 1.40 \\
Percent change in government grants (2016-2017) & 0.142 & 1.23 \\
Percent change in earned income (2016-2017) & 0.344 & 1.49 \\
Organization age (as of 2017) & 18.80 & 16.15 \\
Total assets (logged) & 13.13 & 2.53 \\
Total income (logged) & 13.37 & 1.70 \\
Organization reports no fundraising expenses (1 indicates \$0 in & 0.269 & 0.443 \\
fundraising expenses) & & \\
\hline
\end{tabular}


Table 4: Seemingly Unrelated Regressions of Revenue Sources and Self-Reporting Factors

\begin{tabular}{|c|c|c|c|}
\hline Dependent Variables & $\begin{array}{l}\text { Proportion of Revenue } \\
\text { from Donations }\end{array}$ & $\begin{array}{l}\text { Proportion of Revenue } \\
\text { from Government Grants }\end{array}$ & $\begin{array}{l}\text { Proportion of Revenue } \\
\text { from Earned Income }\end{array}$ \\
\hline \multicolumn{4}{|l|}{ Independent Variables: } \\
\hline \multicolumn{4}{|l|}{ Sensegiving } \\
\hline \multirow[t]{2}{*}{ Symbolic approach } & 0.021 & 0.046 & -0.021 \\
\hline & $(0.051)$ & $(0.035)$ & $(0.047)$ \\
\hline \multirow[t]{2}{*}{ Outcome approach } & $0.102 * *$ & $0.101 * *$ & $-0.085 \% *$ \\
\hline & $(0.046)$ & $(0.032)$ & $(0.042)$ \\
\hline \multirow{2}{*}{ Professionalism approach } & $0.077 * *$ & $0.041^{*}$ & -0.050 \\
\hline & $(0.034)$ & $(0.024)$ & $(0.031)$ \\
\hline \multicolumn{4}{|l|}{ Control Variables } \\
\hline \multirow[t]{2}{*}{ Organization age } & $-0.003 * *$ & $0.002 * * *$ & $0.004 * *$ \\
\hline & $(0.002)$ & $(0.001)$ & $(0.001)$ \\
\hline \multirow{2}{*}{ Total assets (logged) } & $-0.024 * *$ & -0.011 & -0.012 \\
\hline & $(0.011)$ & $(0.007)$ & $(0.010)$ \\
\hline \multirow[t]{2}{*}{ Total income (logged) } & 0.001 & 0.011 & $0.025^{*}$ \\
\hline & $(0.016)$ & $(0.028)$ & $(0.015)$ \\
\hline \multirow{2}{*}{$\begin{array}{l}\text { Organization reports no } \\
\text { fundraising expenses }\end{array}$} & -0.145 & 0.024 & $0.072 * *$ \\
\hline & $(0.040)$ & $(0.028)$ & $(0.036)$ \\
\hline \multirow[t]{2}{*}{ Constant } & $1.031 * * *$ & 0.008 & 0.091 \\
\hline & $(0.145)$ & $(0.101)$ & $(0.132)$ \\
\hline$\chi^{2}$ & $94.68 * * *$ & $89.51 * * *$ & $74.84 * * *$ \\
\hline (p-value) & $(<.001)$ & $(<.001)$ & $(<.001)$ \\
\hline Psuedo $\mathrm{R}^{2}$ & 0.25 & 0.24 & 0.21 \\
\hline $\mathrm{N}$ & 287 & 287 & 287 \\
\hline
\end{tabular}


Table 5: Seemingly Unrelated Regressions of Revenue Change and Self-Reporting Factors

\begin{tabular}{|c|c|c|c|}
\hline Dependent Variables & $\begin{array}{l}\text { Change in Revenue } \\
\text { from Donations }\end{array}$ & $\begin{array}{c}\text { Change in Revenue from } \\
\text { Government Grants }\end{array}$ & $\begin{array}{c}\text { Change in Revenue from } \\
\text { Earned Income }\end{array}$ \\
\hline \multicolumn{4}{|l|}{ Independent Variables: } \\
\hline \multicolumn{4}{|l|}{ Sensegiving } \\
\hline Symbolic approach & $\begin{array}{l}-2.618 \\
(2.441)\end{array}$ & $\begin{array}{l}-0.051 \\
(0.331)\end{array}$ & $\begin{array}{l}-0.773 \\
(6.815)\end{array}$ \\
\hline Outcome approach & $\begin{array}{l}-2.576 \\
(2.196)\end{array}$ & $\begin{array}{l}-0.669 * * \\
(0.297)\end{array}$ & $\begin{array}{l}8.713 \\
(6.132)\end{array}$ \\
\hline Professionalism approach & $\begin{array}{l}2.338 \\
(1.609)\end{array}$ & $\begin{array}{l}0.057^{*} \\
(0.218)\end{array}$ & $\begin{array}{c}2.297 \\
(4.492)\end{array}$ \\
\hline \multicolumn{4}{|l|}{ Control Variables } \\
\hline Organization age & $\begin{array}{l}-0.073 \\
(0.045)\end{array}$ & $\begin{array}{l}-0.001 \\
(0.006)\end{array}$ & $\begin{array}{c}0.069 \\
(0.125)\end{array}$ \\
\hline Total assets (logged) & $\begin{array}{c}0.804 \\
(0.562)\end{array}$ & $\begin{array}{c}0.083 \\
(0.076)\end{array}$ & $\begin{array}{l}-1.364 \\
(1.570)\end{array}$ \\
\hline Total income (logged) & $\begin{array}{c}1.372 \\
(0.832)\end{array}$ & $\begin{array}{c}0.111 \\
(0.113)\end{array}$ & $\begin{array}{l}0.253 \\
(2.322)\end{array}$ \\
\hline $\begin{array}{l}\text { Organization reports no } \\
\text { fundraising expenses }\end{array}$ & $\begin{array}{c}6.645 * * * \\
(1.873)\end{array}$ & $\begin{array}{c}0.248 \\
(0.254)\end{array}$ & $\begin{array}{c}0.529 \\
(5.229)\end{array}$ \\
\hline Constant & $\begin{array}{c}-26.563 * * \\
(7.330)\end{array}$ & $\begin{array}{l}2.404 * * \\
(0.993)\end{array}$ & $\begin{array}{c}10.933 \\
(20.464)\end{array}$ \\
\hline $\begin{array}{l}\chi^{2} \\
\text { (p-value) }\end{array}$ & $\begin{array}{l}44.45 * * \\
(0.033)\end{array}$ & $\begin{array}{l}41.63 * \\
(0.061)\end{array}$ & $\begin{array}{l}17.57 \\
(0.953)\end{array}$ \\
\hline Psuedo $\mathrm{R}^{2}$ & 0.21 & 0.19 & 0.09 \\
\hline $\mathrm{N}$ & 178 & 178 & 178 \\
\hline
\end{tabular}

